\title{
PERBANDINGAN KADAR SOLUBLE fms-LIKE TYROSINE KINASE 1 (sFIt1) SERUM KEHAMILAN NORMAL DENGAN PREEKLAMSI BERAT SERTA HUBUNGANNYA DENGAN TEKANAN DARAH DAN DERAJAT PROTEINURIA
}

\author{
Amillia Siddiq, Johanes C.Mose, Setyorini Irianti \\ Bagian Obstetri dan Ginekologi Fakultas Kedokteran Universitas Padjadjaran/ \\ Rumah Sakit Hasan Sadikin Bandung
}

\begin{abstract}
ABSTRAK
Prediksi dan deteksi dini preeklamsi sangat diperlukan untuk mengurangi angka morbiditas dan mortalitas maternal dan perinatal. Penelitian ini bertujuan mengetahui perbedaan kadar sFIt1 serum kehamilan normal dengan preeklamsi berat (PEB) dan mengetahui hubungan antara kadar sFlt1 serum dan tekanan darah serta derajat proteinuria. Dilakukan studi observasional analitik secara potong silang. Kadar sFlt1 diperiksa dengan ELISA. Analisis statistik menggunakan uji chi kuadrat, uji t, uji Mann-Whitney, koefisien korelasi Rank Spearman, serta uji diagnostik untuk mencari nilai penentu kadar sFIt1. Karakteristik subjek penelitian pada kelompok PEB dan kelompok kontrol tidak berbeda bermakna $(p>0,05)$. Terdapat perbedaan bermakna antara kadar sFlt1 serum kelompok PEB dan kelompok kontrol $(3.827 \pm 471 \mathrm{pg} / \mathrm{mL}$ dan $2.708 \pm 441 \mathrm{pg} / \mathrm{mL} ; \mathrm{p} \leq 0,05)$. Terdapat hubungan positif bermakna antara kadar sFlt1 dan tekanan darah sistolik $(p=0,042 ; p \leq 0,05)$ dan antara kadar sFlt1 dan tekanan darah diastolik $(p=0,041 ; p \leq 0,05)$. Terdapat hubungan bermakna antara kadar sFlt1 dan derajat proteinuria $(p=0,012 ; p \leq 0,05)$. Nilai penentu kadar sFlt1 untuk membedakan penderita PEB dengan hamil normal $2.815 \mathrm{pg} / \mathrm{mL}$ dengan sensitivitas $97,1 \%$, spesifisitas $42 \%$, dan akurasi $69,6 \%$. Terdapat perbedaan bermakna antara kadar sFIt1 pada PEB dan kehamilan normal. Terdapat hubungan bermakna antara kadar sFlt1 dan tekanan darah sistolik, diastolik, serta dengan derajat proteinuria. Nilai penentu (cut-off point) kadar sFIt1 adalah $2.815 \mathrm{pg} / \mathrm{mL}$.
\end{abstract}

Kata kunci: sFlt1, preeklamsi berat, tekanan darah, proteinuria, hamil normal

\section{COMPARISON OF SERUM SOLUBLE fmS-LIKE TYROSINE KINASE 1 (sFIt1) LEVEL IN NORMAL PREGNANCY AND SEVERE PREECLAMPSIA AND ITS ASSOCIATION WITH BLOOD PRESSURE AND DEGREE OF PROTEINURIA}

\begin{abstract}
Prediction and early detection of preeclampsia is very important to reduce maternal and perinatal morbidity and mortality. This research was to find out the difference of serum sFlt1 level between normal pregnancy and severe preeclampsia (SPE) and to determine the correlation of serum sFlt1 level with blood pressure as well as the degree of proteinuria. This was an analytic observational cross sectional study. Measurement of serum sFIt1 level using ELISA. Statistical analysis was performed by using chi square, t test, Mann-Whitney test, Spearman Rank correlation coefficient and diagnostic test for cut-off point determination. The characteristics of the subjects in both groups were not statistically different $(p>0.05)$. There was a significant difference in sFIt1 level between SPE group and control group $(3,827 \pm 471 \mathrm{pg} / \mathrm{mL}$ and $2,708 \pm 441 \mathrm{pg} / \mathrm{mL}$ subsequently; $p \leq 0.05)$. There were significant association between sFlt1 level and systolic blood pressure $(p=0.042 ; p \leq 0.05)$; between sFIt1 level and diastolic blood pressure $(p=0.041$; $p \leq 0.05)$; and between sFlt1 level and degree of proteinuria $(p=0.012 ; p \leq 0.05)$. The cut-off point of sFlt1 level to differentiate SPE from normal pregnancy was $2,815 \mathrm{pg} / \mathrm{mL}$ with sensitivity of $97.1 \%$, specificity $42 \%$ and accuracy of $69.6 \%$. There is statistically significant difference of sFlt1 level in SPE compared to normal pregnancy. Significant association is noted between sFlt1 level and systolic and diastolic blood pressure, as well as degree of proteinuria. The cut-off point of sFlt1 level is $2,815 \mathrm{pg} / \mathrm{mL}$.
\end{abstract}

Keywords: sFlt1, severe preeclampsia, blood pressure, proteinuria

\author{
Alamat Korespondensi: \\ dr. Amillia Siddiq \\ Bagian Kebidanan dan Kandungan-Divisi Fetomaternal FK Unpad/ \\ Rumah Sakit Hasan Sadikin Bandung \\ JI. Pasteur 38 Bandung Telp: 022-2032530
}




\section{PENDAHULUAN}

Hipertensi dalam kehamilan berupa preeklamsi masih merupakan penyebab utama morbiditas dan mortalitas maternal dan perinatal. ${ }^{1,2}$ Belum jelasnya etiologi dan patofisiologi preeklamsi berdampak belum optimalnya penatalaksanaan penyakit ini. Prediksi dan deteksi dini terjadinya preeklamsi sangat diperlukan untuk mengurangi angka morbiditas dan mortalitas maternal dan perinatal. Perhatian dari berbagai penelitian banyak ditujukan pada teori kerusakan endotel sebagai patogenesis preeklamsi. Salah satu substansi yang terlibat dalam proses kerusakan endotel ini adalah soluble fms-like tyrosine kinase-1 (sFlt1). Substansi ini meningkat pada kerusakan endotel pembuluh darah, sehingga pengukuran kadarnya dalam darah dapat memperlihatkan kerusakan endotel yang merupakan salah satu patogenesis awal terjadinya preeklamsi. Hal tersebut menjadi dasar akan dilakukannya penelitian kadar sFIt1 sebagai salah satu penanda kerusakan endotel pada preeklamsi. ${ }^{1,3-5}$ Pada penelitian ini kadar sFIt1 serum ditentukan dengan cara high sensitivity indirect sandwich enzyme linked immunosorbent assay (ELISA) sehingga dapat menilai berapa besar perbedaan kadar SFIt1 pada kehamilan normal dengan penderita preeklamsi berat, serta mencari hubungan antara kadar sFlt1 dan tekanan darah serta derajat proteinuria.

Sampai saat ini pemeriksaan penanda biokimia pada proses kerusakan endotel pembuluh darah yang telah dilakukan di RS Hasan Sadikin di antaranya adalah placental growth factor (PIGF), vascular endothelial growth factor (VEGF) dan fibronektin plasma. Pemeriksaan kadar sFIt1 serum pada preeklamsi belum pernah dilakukan di RS Hasan Sadikin, karena itu dilakukan penelitian tersebut. Walaupun pemeriksaan kadar sFlt1 serum masih cukup mahal, tetapi keuntungannya dapat mendeteksi lebih dini preeklamsi disertai sensitivitasnya yang tinggi sehingga diharapkan di masa depan dapat menjadi salah satu pemeriksaan rutin.

\section{METODE}

Populasi terjangkau adalah semua ibu hamil, baik kehamilan normal maupun dengan penyulit preeklamsi yang menjalani pemeriksaan ke RS Hasan Sadikin Bandung beserta rumah sakit jejaring selama periode penelitian. Sampel penelitian adalah sebagian dari populasi terjangkau yang memenuhi kriteria inklusi sampai terpenuhi jumlah sampel yang diinginkan.

Penentuan besar sampel berdasarkan perhitungan statistik dengan menetapkan taraf kepercayaan $95 \%$ dan power test $80 \%$. Diperoleh 16 sampel untuk tiap kelompok penelitian. Pada penelitian ini diambil 34 sampel untuk kelompok kehamilan dengan preeklamsi berat dan 35 sampel untuk kelompok kehamilan normal.

Penelitian ini dilakukan secara potong silang (cross-sectional study) dengan membandingkan dua kelompok kasus, yaitu kehamilan normal dan preklamsi berat. Dilakukan pemeriksaan kadar sFlt1 serum terhadap kedua kelompok tersebut dan dilakukan pengukuran tekanan darah serta proteinuri untuk menilai beratnya penyakit pada kehamilan dengan preeklamsi.

\section{HASIL}

Dalam penelitian ini didapatkan 69 subjek yang memenuhi kriteria inklusi, yaitu terdiri dari 34 subjek hamil > 20 minggu penderita preeklamsi berat dan 35 subjek hamil normal $>20$ minggu sebagai kontrol. Dari kedua kelompok tersebut diperoleh hasil pengumpulan data karakteristik, tekanan darah sistolik dan diastolik, derajat proteinuria, dan pengambilan darah untuk pemeriksaan kadar sFIt1 di Laboratorium Prodia Jakarta. Agar kedua kelompok penelitian dapat diperbandingkan, pada kedua kelompok tersebut dilakukan matching karakteristik yang meliputi usia, paritas, dan usia kehamilan.

Tabel 1 memperlihatkan bahwa rata-rata usia pada kedua kelompok penelitian menunjukkan tidak ada perbedaan bermakna $(p=0,093)$. Demikian pula halnya paritas tidak menunjukkan perbedaan yang bermakna $(p=0,851)$. Subjek penderita preeklamsi berat terbanyak $(61,8 \%)$ berada pada kelompok usia kehamilan $\geq 37$ minggu, tetapi rata-rata usia kehamilan antara kedua kelompok penelitian tidak bermakna $(p>0,05)$. Dengan demikian, kedua kelompok penelitian homogen sehingga layak dapat diperbandingkan.

Tabel 2 menyajikan data perbandingan rata-rata kadar sFlt1 serum pada kelompok preklamsi berat dan kelompok kontrol. Berdasarkan uji Mann-Whitney, diperoleh hasil bahwa kadar sFlt1 serum pada kelompok preeklamsi berat lebih tinggi jika dibandingkan dengan kelompok normal yang secara statistik bermakna $(p<0,05)$.

Untuk mengetahui apakah kadar sFlt1 dapat dipakai sebagai alat prediksi preeklamsi berat dilakukan analisis berdasarkan kurva ROC. Dari kurva ROC diperoleh cut-off point untuk sFlt1 adalah $\geq 2.815 \mathrm{pg} / \mathrm{mL}$. Berdasarkan cut-off point dapat dibuat tabel $2 \times 2$ seperti ditunjukkan pada Tabel 3. Berdasarkan Tabel 3 diperoleh besarnya sensitivitas $97,1 \%$, spesifisitas $42 \%$, dan akurasi $69,6 \%$. 
Tabel 1 Karakteristik Subjek Penelitian

\begin{tabular}{|c|c|c|c|c|}
\hline \multirow[b]{2}{*}{ Karakteristik } & \multicolumn{2}{|c|}{ Kelompok Penelitian } & \multirow[b]{2}{*}{ Total } & \multirow[b]{2}{*}{$\begin{array}{c}\text { Uji } \\
\text { statistik }\end{array}$} \\
\hline & $\begin{array}{c}\text { Preeklamsi Berat } \\
\qquad(n=34)\end{array}$ & $\begin{array}{c}\text { Normal } \\
(n=35)\end{array}$ & & \\
\hline \multicolumn{5}{|l|}{ Usia (tahun) } \\
\hline $20-24$ & $2(5,9 \%)$ & $9(25,7 \%)$ & $11(15,9 \%)$ & \\
\hline $25-29$ & $8(23,5 \%)$ & $9(25,7 \%)$ & $17(24,6 \%)$ & \\
\hline $30-34$ & $9(26,5 \%)$ & $10(28,6 \%)$ & $19(27,5 \%)$ & $\chi^{2}=7.962$ \\
\hline $35-39$ & $11(32,3 \%)$ & $4(11,4 \%)$ & $15(21,7 \%)$ & $p=0,093$ \\
\hline $40+$ & $4(11,8 \%)$ & $3(8,6 \%)$ & $7(10,1 \%)$ & \\
\hline Rata-rata $( \pm S D)$ & $32,5(5,30)$ & $29,4(6,4)$ & & \\
\hline Rentang & $22-42$ & $20-43$ & & \\
\hline \multicolumn{5}{|l|}{ Paritas } \\
\hline 0 & $4(11,8 \%)$ & $6(17,1 \%)$ & $10(14,5 \%)$ & $\chi^{2}=1.362$ \\
\hline $1-3$ & $30(88,2 \%)$ & $29(82,9 \%)$ & $24(85,5 \%)$ & $\mathrm{p}=0,851$ \\
\hline \multicolumn{5}{|c|}{ Usia Kehamilan (minggu) } \\
\hline \multicolumn{5}{|l|}{$20-27$} \\
\hline $28-36$ & & $2(5,7 \%)$ & $2(2,9 \%)$ & $t=0,07$ \\
\hline \multirow[t]{2}{*}{$\geq 37$} & $13(38,2 \%)$ & $8 \quad(22,6 \%)$ & $21(30,6 \%)$ & $p=0,945$ \\
\hline & $21(61,8 \%)$ & $25(71,7 \%)$ & $46(66,5 \%)$ & \\
\hline Rata-Rata ( $\pm S D)$ & $37,1(2,6)$ & $37,02(4,3)$ & & \\
\hline Rentang & $32-41$ & $24-42$ & & \\
\hline
\end{tabular}

Keterangan $: \chi^{2}=$ uji chi kuadrat; $\mathrm{t}=$ uji $t$; nilai $\mathrm{p}$ atas dasar $\mathrm{p}=0,05$ signifikan

Tabel 2 Perbandingan Rerata Kadar sFlt1 Serum Antara Kelompok Preeklamsi Berat dan Kelompok Kontrol

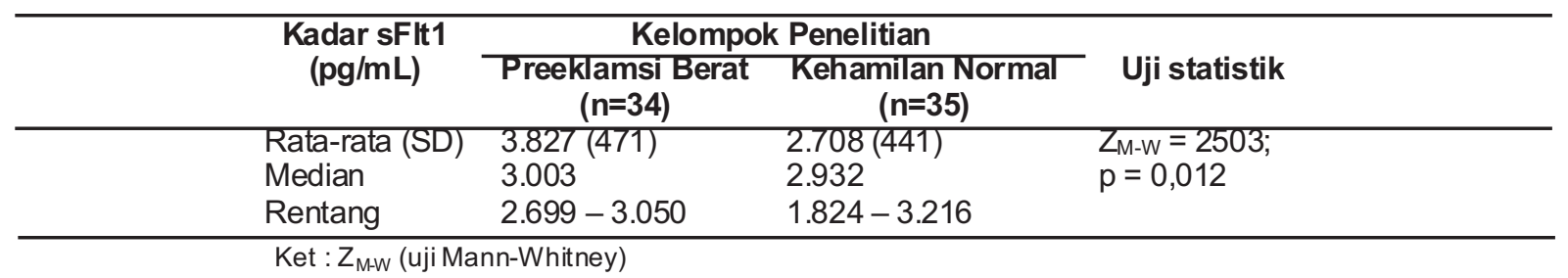

Tabel 3 Cut-off Point Kadar sFlt1 Serum dalam Memprediksi Preeklamsi Berat

\begin{tabular}{lcccccc}
\hline Cut-off point $)$ & $\begin{array}{c}\text { Preeklamsi } \\
\text { berat } \\
\mathbf{n = 3 4}\end{array}$ & $\begin{array}{c}\text { Kehamilan } \\
\text { Normal } \\
\mathbf{n = 3 5}\end{array}$ & Sensitivitas & Spesifisitas & Akurasi & OR (95\% Cl) \\
\hline & $33(97,1 \%)$ & $20(57,1 \%)$ & $97,1 \%$ & $42 \%$ & $69,6 \%$ & 24,75 \\
2.815 & $1(2,9 \%)$ & $15(42,9 \%)$ & & & $(3,03-201,93)$ \\
\hline$<2.815$ & $15 \%$ & & \\
\hline
\end{tabular}

Keterangan: *) berdasarkan kurva ROC (Rec eiver Operating Characteristics)

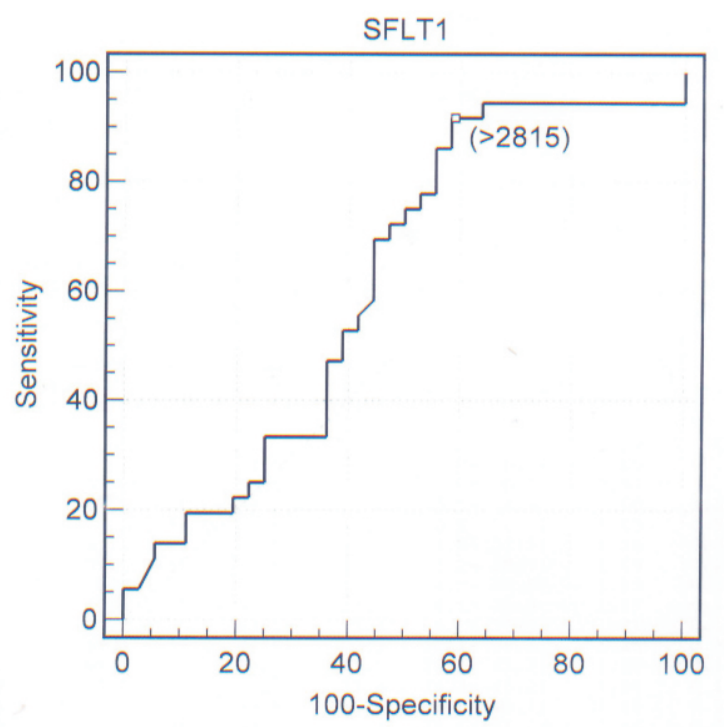

Gambar Kurva ROC (Cut-off Point) Kadar sFIt1 Serum 
Tabel 4 Hubungan Antara Kadar sFlt1 Serum dan Tekanan Darah

\begin{tabular}{ccc}
\hline Variabel & \multicolumn{2}{c}{ Nilai statistik } \\
\hline Hubungan Kadar sFlt1 dengan Sistolik & $\mathbf{r}$ & $\mathbf{p}$ \\
Hubungan Kadar sFlt1 dengan Diastolik & $0,21^{*}$ & 0,042 \\
\hline${ }^{*}$ koefisien korelasi Rank Spearman & $0,21^{*}$ & 0,041 \\
\hline
\end{tabular}

Tabel 5 Hubungan Antara Kadar sFlt1 Serum dan Derajat Proteinu ria

\begin{tabular}{lcc}
\hline \multicolumn{1}{c}{ Variabel } & \multicolumn{2}{c}{ Nilai statistik } \\
& $\mathbf{r}$ & $\mathbf{p}$ \\
\hline $\begin{array}{l}\text { Hubungan Kadar sFlt1 dengan Derajat } \\
\text { Proteinuria }\end{array}$ & $0,299^{*}$ & 0,012 \\
\hline${ }^{*}$ koefisien korelasi Rank Spearman & & \\
\hline
\end{tabular}

Berdasarkan Tabel 4 terlihat bahwa hasil analisis hubungan antara kadar sFIt1 serum dan tekanan darah sistolik dengan analisis korelasi rank Spearman pada derajat kepercayaan $95 \%$ menunjukkan bahwa terdapat hubungan bermakna antara kadar sFIt1 serum dan tekanan darah sistolik, dengan nilai $p=0,042$ (nilai $p \leq 0,05$ ).

Tabel 4 menunjukkan pula bahwa hasil analisis hubungan antara kadar sFIt1 serum dan tekanan darah diastolik dengan analisis korelasi rank Spearman pada derajat kepercayaan $95 \%$ menunjukkan bahwa terdapat hubungan bermakna antara tekanan darah diastolik dan kadar sFlt1 serum, dengan nilai $p=0,041$ (nilai $p \leq 0,05$ ).

Berdasarkan Tabel 5 terlihat bahwa hasil analisis hubungan antara kadar sFIt1 serum dan derajat proteinuria dengan analisis korelasi Rank Spearman pada derajat kepercayaan 95\% menunjukkan bahwa terdapat hubungan bermakna antara kadar sFlt1 serum dan derajat proteinuria, dengan nilai $p=0,012$ (nilai $p \leq 0,05)$.

\section{PEMBAHASAN}

Enam puluh sembilan subjek penelitian terdiri dari 34 kelompok preeklamsi berat dan 35 kelompok kontrol (kehamilan normal). Karakteristik subjek penelitian meliputi usia, paritas, dan usia kehamilan. Dari segi usia, tampak rerata usia pada kelompok preeklamsi berat adalah 32,5 tahun (SD 5,30) dengan rentang usia 22-42 tahun. Pada kelompok kontrol, rerata usia adalah 29,4 tahun (SD 6,4) dengan rentang usia 20-43 tahun. Atas dasar uji $x^{2}$ pada taraf $p=0,05$ diperoleh bahwa rata-rata usia kelompok preeklamsi berat tidak berbeda secara bermakna jika dibandingkan dengan rerata usia kelompok kontrol $(p=0,093)$. Demikian pula untuk paritas, tidak terdapat perbedaan bermakna $(p=0,851)$ antara kelompok preeklamsi berat dan kelompok kontrol. Usia kehamilan menunjukkan bahwa jumlah terbanyak subjek yang mengalami preeklamsi berat adalah pada usia kehamilan $\geq$ 37 minggu sebanyak $61,8 \%$, sedangkan yang paling sedikit adalah pada usia kehamilan 28-36 minggu $(38,2 \%)$, serta tidak ada perbedaan yang bermakna dalam usia kehamilan di antara kelompok preeklamsi berat dan kelompok kontrol $(p=0,945)$. Atas dasar analisis statistik pada ketiga variabel karakteristik subjek penelitian, kedua kelompok penelitian tersebut homogen sehingga dapat diperbandingkan.

Dari Tabel 2 terdapat perbedaan rata-rata kadar sFIt1 yang bermakna antara kelompok preeklamsi berat dan kelompok kehamilan normal. Pada preeklamsi berat kadar sFlt1 lebih tinggi yaitu $3.827 \mathrm{pg} / \mathrm{mL}$ dibandingkan pada kehamilan normal $2.708 \mathrm{pg} / \mathrm{mL}$. Hal ini sesuai dengan penelitian Levine et al yang menyatakan bahwa kadar sFlt1 serum pada preeklamsi lebih tinggi daripada kehamilan normal. Simpulannya adalah hasil analisis penelitian ini mendukung hipotesis bahwa kadar sFlt1 serum pada penderita preeklamsi berat lebih tinggi daripada kehamilan normal. ${ }^{9-13}$

Walaupun patogenesis preeklamsi belum dimengerti dengan baik, penyebab kerusakan endotel bisa memegang peran penting. Salah satu substansi yang penting terlibat dalam proses kerusakan endotel tersebut adalah sFIt. Substansi tersebut berperan penting dalam aspek patofisiologi penyakit preeklamsi ini. Dari penelitian yang dilakukan penulis tampak bahwa kadar sFlt1 meningkat pada pasien preeklamsi berat jika dibandingkan dengan kontrol.

Hasil penelitian mengenai kadar sFlt1 serum pada preeklamsi berat ini $3.827 \pm 471$ $\mathrm{pg} / \mathrm{mL}$ sejalan dengan hasil penelitian Levine et al yang menghasilkan kadar rerata sFlt1 sebesar $3.083 \pm 657 \mathrm{pg} / \mathrm{mL}^{13}$

Dalam memprediksi preeklamsi berat, sFlt1 serum berturut-turut mempunyai sensitivitas, spesifisitas, dan akurasi sebesar $97,1 \%$, 42\%, dan 69,6\% (Tabel 4), setelah diperoleh cut-off point sebesar 2.815 dengan memakai kurva ROC (Receiver Operating Characteristics) (Gambar). Sensitivitas, spesifisitas, dan akurasi ini cukup tinggi. Dengan demikian, berdasarkan sensitivitas, spesifisitas, dan akurasi sebesar tersebut, kadar sFlt1 di atas atau sama dengan $2.815 \mathrm{pg} / \mathrm{mL}$ sudah memberikan peluang 24,75 kali $(\mathrm{OR}=24,75)$ untuk mengalami preeklamsi berat 
jika dibandingkan dengan pasien yang mempunyai kadar sFlt1 $<2.815 \mathrm{pg} / \mathrm{mL}$. Simpulannya adalah kadar sFlt1 serum dapat digunakan sebagai prediktor preeklamsi berat jika kadarnya lebih atau sama dengan 2.815 $\mathrm{pg} / \mathrm{mL}$.

Seperti telah diketahui, preeklamsi didefinisikan sebagai timbulnya hipertensi dan onset baru proteinuria $(>300 \mathrm{mg}$ protein urin dalam 24 jam) pada wanita yang mula-mula tidak mengalami proteinuria. Hipertensi didefinisikan sebagai mempunyai tekanan darah sistolik $\geq 140 \mathrm{mmHg}$ dan/atau tekanan darah diastolik $\geq 90 \mathrm{mmHg}$ ketika diukur dua kali setelah penderita istirahat, sedangkan kelompok kontrol mempunyai tekanan darah dalam rentang normal (tekanan darah sistolik $<140 \mathrm{mmHg}$ atau tekanan darah diastolik $<90$ $\mathrm{mmHg}$ ).

Pada Tabel 4 terlihat kadar sFIt1 serum dan tekanan darah sistolik mempunyai hubungan yang bermakna $(p \leq 0,05)$ dengan analisis korelasi Rank Spearman (nilai $p=0,042$ ). Hal yang sama terjadi pula pada hubungan sFlt1 terhadap tekanan darah diastolik, dengan analisis korelasi Rank Spearman terdapat hubungan yang bermakna antara kadar sFlt1 serum dan tekanan darah sistolik (nilai $p=0,041$ ).

Sesuai dengan teori kerusakan endotel, sFlt1 ini meningkat akibat disfungsi endotel, seperti dikemukakan oleh Lam et al ${ }^{9}$ bahwa preeklamsi dianggap merupakan suatu penyakit akibat disfungsi endotel yang meningkatkan aktivitas trombosit, meningkatkan produksi vasokonstriktor, dan menurunkan produksi vasodilator, sehingga dapat meningkatkan tekanan darah.

Terlihat pada Tabel 5 terdapat hubungan yang bermakna antara kadar sFlt1 dan derajat proteinuria dengan nilai $p=0,012$ (nilai $p \leq 0,05$ ). Hal ini sesuai dengan penelitian Levine et al, ${ }^{13}$ yang mengatakan bahwa kadar sFlt1 serum pada pasien preeklamsi berat secara bermakna lebih tinggi daripada kehamilan normal, sesuai dengan keparahan preeklamsi yang salah satu penandanya adalah peningkatan derajat proteinuri.

Simpulan penelitian ini adalah kadar sFIt1 serum pada penderita preeklamsi berat lebih tinggi daripada kehamilan normal. Terdapat hubungan antara peningkatan kadar sFlt1 serum dan peningkatan tekanan darah penderita preeklamsi berat, serta antara peningkatan kadar sFlt1 serum dan peningkatan derajat proteinuria penderita preeklamsi berat.

\section{DAFTAR PUSTAKA}

1. Cunningham FG, Norman FG, Kenneth JL, Larry
CG, John CH, Katharine DW. Williams obstetrics. Edisi ke-22. New York: Williams and Wilkins; 2005.

2. Hallak M. Hypertension in pregnancy. Dalam: James DK, Steer PJ, Weiner CP, Gonik B, penyunting. High risk pregnancy management option. Edisi ke 2. London: WB Saunders; 2001. h. 639-63.

3. Creasy RK, Resnik R. Maternal fetal medicine principles and practice. Edisi ke 3. London: WB Saunders; 2004.

4. Rodger GM. Hemostatic properties of normal and pertubed vascular cells. FASEB J. 1988;2:11623.

5. Tuder RM, Flook BE, Voelkel NF. Increased gene expression for VEGF and VEGF receptors KDR/Flk and Flt in lung exposed to acute or chronic hypoxia. J Clin Invest. 1995;95:1798807.

6. Gunanegara R. Perbandingan antara kadar vascular endothelial growth factor bebas serum pada kehamilan normal dan preeklamsi berat. Tesis. Bandung: Fakultas Kedokteran Universitas Padjadjaran; 2005.

7. Irianti S, Wijayanegara H, Mose JC. Korelasi antara kadar placental growth factor (PIGF) pada pertengahan trimester kedua dengan kejadian preeklamsi dan pertumbuhan janin terhambat. Tesis. Bandung: Fakultas Kedokteran Universitas Padjadjaran; 2008.

8. Santoso B. Perbandingan antara kadar fibronektin plasma pada kehamilan normal dan preeklamsi-eklamsi serta hubungannya dengan tekanan darah dan derajat proteinuri. Tesis. Bandung: Fakultas Kedokteran Universitas Padjadjaran; 2005.

9. Lam C, Lim KH, Karumanchi SA. Circulating angiogenic factors in the pathogenesis and prediction of preeclampsia. Hypertension. 2005; 46:1077-85.

10. Berg CJ, Atrash HK, Koonin LM, Tucker M. Pregnancy related mortality in The United States 1987-1990. Obstet Gynecol. 1996;88:161-7.

11. Finkel RS, Zarlengo KM. Soluble fms-like tyrosine kinase 1. N Engl J Med. 2004;351:22412.

12. Shibata E, Rajakumar A, Powers R, Larkin R, Gilmour, Bodnar L, et al. Soluble fms-like tyrosine kinase 1 is increased in preeclampsia but not in normotensive pregnancies with small-forgestational-age neonates: Relationship to circulating placental growth factor. J Clin Endocrinol Metab. 2005;90:4895-903.

13. Levine RJ, Qian C, Maynard SE, Yu KF, Epstein $\mathrm{FH}$, Karumanchi SA. Serum sFlt1 concentration during preeclampsia and mid trimester blood pressure in healthy nulliparous women. Am J 
Obstet Gynecol. 2006;194:1034-41.

14. Maynard SE, Min JY, Merchan J, Lim KH, Li J, Mondal S, et al. Excess placental soluble fms-like protein kinase 1 (sFlt1) may contribute to endothelial dysfunction, hypertension, and proteinuria in preeclampsia. J Clin Invest. 2003; 111:649-58. 